\title{
The Implementation of HOTS-based ESCOTING (Relay Writing and Collaborative Writing) Model in Writing Fable at a Primary School
}

\author{
Tatat Hartati ${ }^{*}$, Bagja Dani Magribi ${ }^{2}$, Rajji K. Adiredja ${ }^{3}$ \\ ${ }^{123}$ Universitas Pendidikan Indonesia, INDONESIA
}

Received 15 November 2020 • Revised 17 February 2021 • Accepted 24 March 2021

\begin{abstract}
Language skills are the most important part of language learning at primary schools that need to be taken seriously. If not, then this results in low writing skills of students in expressing ideas in writing. So, students' thinking skills or what so-called Higher Order Thinking Skills (HOTS) are essential to be developed by teachers through learning. This study aims to determine the implementation of the HOTS-based ESCOTING model in writing skills of fables at primary school level. The method used was a pre-experimental research design with a single treatment design (one-shot case study). The sample used in this study was 23 second-grade students of a primary school in Bandung. The results showed that there was a significant increase in student learning outcomes in writing skills. From these results it can be concluded that the implementation of the HOTS-based ESCOTING model can be used as a solution by the teacher to develop students' writing skills, especially in writing fables for the second-grade students.
\end{abstract}

Keywords: ESCOTING, HOTS, Writing Skill

\section{INTRODUCTION}

Language is the most important component in individual life. Learning the language that we will use in everyday life is an individual human need. Humans are social creatures or often known as homo homini socius. Humans need the presence of other people in their lives. This arises because of the awareness of fulfilling the needs cannot be done alone. In this fulfillment, humans are definitely need interaction with other people. In human interaction requires communication. Communication is a reciprocal delivery of messages between communicators (people who deliver messages) and communicants (people who receive messages).

Communication can be performed in spoken or written forms. Oral communication is identical to the ability to speak and listen (listen). Meanwhile, written communication requires reading, listening and writing skills. The ability to read, listen, write and speak are language skills (Tarigan, 2008). Writing is the ability to use written language patterns to express an idea or message. In addition, writing is a process of compiling notes and communicating meaning in a double level that is interactive and directed to achieve certain goals using a conventional sign system that can be seen or read. Writing can also be interpreted as a process of describing a language so that the message to be conveyed by the writer can be understood by the reader (Tarigan, 1986). In addition, Boroditsky (2011) in Suherdi (2016) provides evidence of the influence of language on thinking. Language is certainly more involved in many aspects of human life than experts have believed, because there are a few thinking activities that does not involve language. From this statement, language learning should not be limited to developing language skills, but it is supposed to be able to help children develop the thinking skills needed to master all subjects in the curriculum (Suherdi, 2016).

Writing skill, as noted by language teaching experts, is placed at the highest level in the language acquisition process because this skill refers to productive skills that can only be obtained after listening, speaking and reading skills. That is why, writing is regarded as the most difficult language skill. Even though writing skill is are the most difficult to apply language use, it is very important in social life. We often find written activities in daily life such as writing letters, reports, books, articles and others. In fact, Tarigan (1992) states that an indication of a nation's (c) 2021 by the authors; licensee PGSD UMP. This article is an open access article distributed under the terms and conditions of the Creative Commons Attribution License (http://creativecommons.org/licenses/by/4.0/). 
progress can be seen from the progress of written communication of the nation itself. Seeing from the above, the item is of course ready to write to get used to it as early as possible. It is not surprising that writing in primary school design is the most dominant aspect of learning Indonesian compared to others.

Language skills are skills that emphasize receptive skills and productive skills. Four aspects of language skills that embrace language teaching are: (1) listening skills, (2) speaking skills, (3) reading skills, (4) writing skills (Tarigan, 1996). Based on the four language skills, writing activities are the language skills most lately mastered by students. Therefore, writing subject is more difficult and tiring, students often refuse to write too much and there also exist students who find it difficult and lazy to learn to write. A person's writing skill has a very important role in life, writing can also support one's success. Through writing skills, a person can involve himself in the global competition that is currently happening. Writing skill is an activity that involves a variety of other skills, including arranging thoughts and feelings by using words in the form of appropriate sentences, and arranging them in one paragraph. For students who have mastered writing skill, they will get a score that exceeds the KKM (minimum completeness criteria) that the school has determined. The components used in the assessment of writing skills are: use of capital letters, use of punctuation marks, sentence structure and the suitability of story content with a predetermined theme. A person can be said to have the ability to speak language if the person is able to use good and correct Indonesian according to predetermined rules. Writing skill is one of the skills that still have many obstacles in its application.

Based on the results of a preliminary study in the second-grade students in one of primary schools in Bandung, it showed that their writing skill was still low. This problem occurred because of the lack of variation in the methods used by the teachers, the teachers used the 'lecture' method more so that it caused students' boredom and laziness. Boredom was what caused students to be less interested in learning Indonesian, especially when writing. This has an effect on student learning outcomes which results in a lack of students' ability to write relay stories. The problems faced by students were: (1) Lack of students' initial knowledge in the form of capital letter placement and dot punctuation. So that students had difficulty in combining words into coherent sentences, and (2) Students had difficulty in expressing ideas and ideas in the form of simple stories.

To create fun and effective learning, the teacher should create a student-centered learning process and the teacher should also be able to utilize appropriate and attractive models, media and methods for students. To be able to improve students' abilities in writing fable stories, several things can be achieved, one of which is the implementation of the learning model. One learning model that is suitable for writing fable stories is the relay writing model, because this learning model is student-centered and makes learning to write fable stories fun by seeing student learning outcomes from the use of correct capital letters and correct punctuation. Relay writing or chain writing is one of the active learning or learning by doing methods which aims to make classroom learning more active and fun (Cahyono, 2011). The steps in the chain writing learning model or relay writing (Syathariah, 2011) are as follows: (1) The teacher explains a theme and material to be taught; (2) The teacher asks the students to make groups of 5-6 people; (3) The teacher asks students to make one opening sentence; (4) After the student writes the opening sentence, the student becomes the first person. Then at the first count, the teacher gave the order to raise the book height of each student, on the second count the teacher asked the students to hand over their books to their right-hand friend; (5) The student becomes the second person who must continue his friend's essay by adding one further sentence. Students are required to see the previous sentence to continue the next essay; (6) After the second person is finished, the teacher returns to counting to be submitted to the friend to his right, and so on rotates clockwise, until the time determined by the teacher; (7) After the teacher's appointed time, the exercise book should be returned to its original owner. The owner of the book reads the essays that are written in a chain and marks the sentences that are discordant or not connected; (8) The teacher asks one of the students to write down the results of writing a chain on the writing board; and (9) then the teacher and students correct the writing product together.

The ESCOTING model was predicted to improve students' ability to identify words to create a fable. Seeing the above problems, the researcher applied HOTS-based ESCOTING (relay writing and collaborative writing) model. Thinking skills certainly need to be developed in students through the learning process. This is in line with Resnik's explanation, in the Ministry of Education and Culture (2018) that HOTS is a complex thought process in describing material, making conclusions, building representations, analyzing, and building relationships by involving the most basic mental activities.

Based on the explanation above, the purpose of this study was to determine the implementation of HOTS-based ESCOTING models in writing fable at primary school. The sample in this study was 23 second-students. The Implementation of learning by applying the HOTS-based ESCOTING model was carried out in the experimental class. This research was expected to be an alternative learning in developing writing skills for students, especially primary school teachers. In addition, teachers were also expected to gain new knowledge related to the assessment of writing fable. 


\section{Methods}

The research method used in this research was pre-experimental design with a single treatment design (oneshot case study). One-shot case study is an experiment carried out without a comparison group and also without a preliminary test (Arikunto, 2005). The researchers gave treatment to the subject (X), then, they observed it (Y). In this design, a group of research subjects received treatment, then measured the variables to be observed. The variables analyzed in this study were: $(1)$ the treatment variable $(X)$, namely the application of the HOTS-based ESCOTING model which is a treatment of this study; (2) The observation variable (Y), namely the ability to write fable by paying attention to the use of capital letters and punctuation marks.

\section{Instrument}

The research instruments used in this study are as follows: (1) Observation, observation was made by direct observation of changes that occur after being given treatment; (2) Interviews were free guided interviews. Interview guidelines were free guided interviews, namely a combination of free interviews and guided interviews. In conducting interviews, the interviewer carries a guideline that is only an outline of the things to be asked (Arikunto, 2002). In this study, the interviewees were teachers who taught in second grade; (3) Documentation in this study the researcher investigated written objects such as books, documents, regulations, diary notes and so on that already exist from foundations or schools in the form of data about the curriculum vitae and history of the sample. (Arikunto, 2002); and (4) Tests, tests are a series of questions or exercises and other tools used to measure the skills, intelligence knowledge, abilities or talents possessed by individuals or groups (Arikunto, 2006). In this study, using a test tool by writing the story on a piece of paper, writing the fable was a test to determine the proper and correct writing of capital letters and punctuation marks.

\section{Procedures}

The learning process began by providing a review of the material using capital letters and punctuation marks, then a learning outcome test was held by applying the ESCOTING model to determine student learning outcomes. There were several outlines of the implementation of learning activities by applying the Audio ESCOTING model, including:

1. Introduction, the researchers performed classroom conditioning and ice breaking classically.

2. The core activity, the researchers provided an explanation regarding the use of capital letters and punctuation marks. When given the material, most students paid less attention and seemed confused about the material presented. Researchers provided the stages of implementing the Audio ESCOTING model and provided opportunities for students in case they faced some difficulties. The researchers gave a practice test to write fable by applying the ESCOTING Audio model on the paper that had been provided.

3. Closing, at the end of the lesson the researcher asked the difficulties experienced by students when writing fable.

\section{Analisis Data}

In this study, the data analysis used was descriptive analysis to measure the tendency to center and the size of the distribution. The results of data analysis could be used to describe the distribution of the scores by grouping them into a standard scale, by grouping the scores into a scale of categories, then it would be seen which categories appeared in the most frequency. Furthermore, testing the hypothesis, which began with the normality test to test whether the distribution of existing data was normally distributed or not.

\section{RESULTS AND DISCUSSION}

In this study the dependent variable was "writing fable" (Y) from the independent variable treatment "the implementation of HOTS-based ESCOTING model" (X). The instrument used in this study was an assessment of the use of letters and punctuation marks in the students' writing fable. After conducting the research, the learning outcomes of the experimental group, which amounted to 23 second-grade students, were obtained in the table below.

Table 1

Final Score of The Experimental Group 


\begin{tabular}{|c|c|c|}
\hline No. & Code & Score \\
\hline 1 & $2-\mathrm{A}$ & 70 \\
\hline 2 & $2-B$ & 90 \\
\hline 3 & $2-C$ & 70 \\
\hline 4 & 2-D & 80 \\
\hline 5 & $2-E$ & 80 \\
\hline 6 & $2-\mathrm{F}$ & 60 \\
\hline 7 & $2-G$ & 80 \\
\hline 8 & $2-\mathrm{H}$ & 80 \\
\hline 9 & 2-I & 80 \\
\hline 10 & $2-\mathrm{J}$ & 80 \\
\hline 11 & $2-K$ & 80 \\
\hline 12 & 2-L & 80 \\
\hline 13 & 2-M & 80 \\
\hline 14 & $2-\mathrm{N}$ & 80 \\
\hline 15 & $2-\mathrm{O}$ & 80 \\
\hline 16 & $2-\mathrm{P}$ & 80 \\
\hline 17 & $2-Q$ & 80 \\
\hline 18 & $2-R$ & 80 \\
\hline 19 & $2-S$ & 80 \\
\hline 20 & $2-\mathrm{T}$ & 70 \\
\hline 21 & $2-U$ & 70 \\
\hline 22 & $2-\mathrm{V}$ & 80 \\
\hline 23 & $2-W$ & 80 \\
\hline
\end{tabular}

The descriptive analysis for the size of the tendency to converge and the size of the distribution for the results in Table 1 can be seen in Table 2.

Table 2

The value of the central tendency and distribution of the experimental group learning outcomes

\begin{tabular}{|l|r|}
\hline $\mathrm{N}$ & Valid \\
\hline Mean & 77.8261 \\
\hline Median & 80.0000 \\
\hline Mode & 80.00 \\
\hline Std. Deviation & 5.99736 \\
\hline Minimum & 60.00 \\
\hline Maximum & 90.00 \\
\hline
\end{tabular}

The results of the data analysis can be used to describe the distribution of scores by grouping them into a standard scale, by grouping the scores into a scale of categories, then it will be seen which categories appear in the most frequent frequencies. The frequency distribution of test scores based on their categories can be seen in Figure 1. 


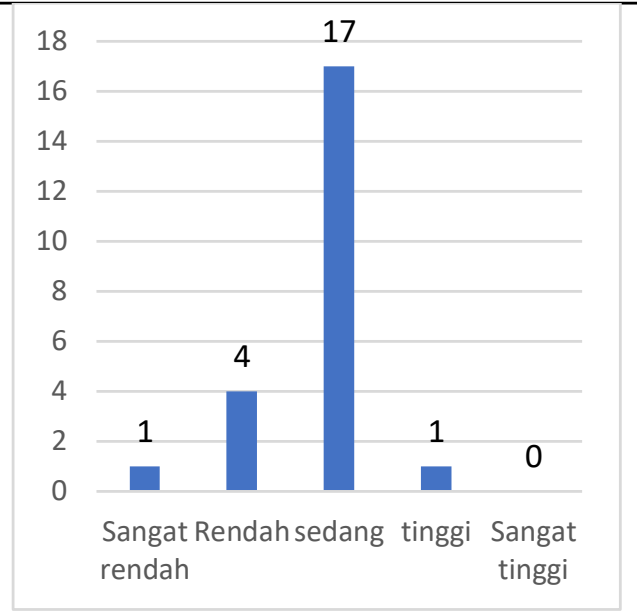

Figure 1. Histogram: Test Score Distribution

The description of above distribution:

$\begin{array}{ll}\leq 60 & : \text { Very Low } \\ 61 \text { up to } \leq 70 & \text { : Low } \\ 71 \text { up to } \leq 80 & \text { : Average } \\ 81 \text { up to } \leq 90 & \text { : High } \\ 91 \text { up to } \leq 100 & \text { : Very High }\end{array}$

The histogram shows the number of frequencies from the very low, low, average, high, and very high categories. It can be seen in Table 1 and Figure 1 that in the very low score category was: 1 respondent (4.34\%) in very low category, 4 respondents $(17.4 \%)$ in the low category, 17 respondents $(73.9 \%)$ average, 1 respondent $(4.3 \%)$ in high category, and 0 respondent $(0 \%)$ in very high category.

Based on the histogram, it can be seen that the average student falls into the average category. The Average value shows that student learning outcomes are above the KKM value. To test the hypothesis, the right group test is carried out with the following steps:

1. Normality Test

Normality test is done to test whether the distribution of existing data is normally distributed or not. Normality test is performed using the Chi Square method. Before testing with the Chi Square method, the data must be arranged in the form of a frequency distribution. Based on the data in Table 1, the highest value is 90 and the lowest value is 60 , with a value range of 30 . With 23 data, the number of classes obtained is 4 classes. So that the class length is 8 . The frequency distribution table can be seen in Table 3.

Tabel 3. The Frequency Distribution of the Final Score Results for the Experimental Group

By applying level of significance $a=5 \%$ with $\mathrm{dk}=\mathrm{k}-1$. If $\chi^{2}$ count $<\chi^{2}$ table then the data is normally distributed and vice versa if $\chi^{2}$ count $>\chi^{2}$ table then data are not normally distributed. The results of normality test can be seen in Table 4.

Table 4

The Result of Normality Test

\begin{tabular}{|l|l|l|l|}
\hline$X^{2 \text { count }}$ & Dk & $X^{2}$ table & Description \\
\hline 9,27 & 4 & 9,49 & Normal \\
\hline
\end{tabular}

Based on the table above, it can be concluded that the $\chi^{2}$ count $=(9,27)<\chi^{2}$ table $=(9,49)$ so it normal distribution 
2. Hypothesis Test

To Calculate the hypothesis below equation is applied:

In which: $s=\sqrt{\frac{\sum(x-\bar{x})^{2}}{n-1}}$

$$
t=\frac{\bar{x}-\mu}{\frac{s}{\sqrt{n}}}
$$

Hypothesis used:

$\mathrm{H}_{\mathrm{o}}: \mu_{\mathrm{o}} \leq 70(\mathrm{KKM})$

$\mathrm{H}_{1}: \mu_{\mathrm{o}}>70(\mathrm{KKM})$

Keterangan:

$\mu_{\mathrm{o}} \quad=$ The average score of learning outcomes in line with one-shot experiment method

$\mathrm{KKM}=$ Kriteria ketuntasan minimum (minimum completeness criteria)

Right-hand test criteria if $t_{\text {table }}>t_{\text {count }}$ with $d k=n-1, a=5 \%$ then $H_{o}$ accepted and $H_{1}$ rejected for the value of the other $t$.

Test result of t-test can be seen in below Table 5 .

Table 5

The Result of of $\mathrm{t}$-test

\begin{tabular}{|c|c|c|c|c|}
\hline $\bar{x}$ & $\mathrm{~S}$ & $\mathrm{n}$ & $\mu_{\mathrm{o}}$ & $\mathrm{t}$ \\
\hline 77,8 & 5,99 & 23 & 70 & 6,24 \\
\hline
\end{tabular}

Based on the results of the $t$-test on the right side, the $t_{\text {test }}$ value was 6.24 and the $t_{\text {table }}$ value with $d k=22$ and a significant level of $5 \%$ was 1.717 . Thus, the value of $t_{\text {coun }} t>t_{\text {table. }}$. From the test results, it can be concluded that Ho is rejected and H1 is accepted. So, it can be concluded that the HOTS-based ESCOTING model is effective in increasing the ability to write fable.

\section{DISCUSSION}

Based on the analysis of the result formulations shown in the table, it has shown that this model is very helpful in the student learning process and is very significant in experiencing changes as seen from the results that show student scores above KKM. The HOTS-based ESCOTING model is considered effective in increasing students' interest in writing, in addition to having fun, it also makes children faster and tidier in their writing.

\section{CONCLUSION}

Based on the results of the research described above, it can be concluded that the results of learning writing skills of second-grade students of primary school on fable writing material using the HOTS-based ESCOTING model have increased, it can be seen from the results of data carried out before and after applying the model; then, the HOTS-based ESCOTING model is considered effective to improve students' writing fable..

\section{REFERENCES}

[1] Arikunto, S. (2002). Metodologi Penelitian Suatu Pendekatan Proposal. Jakarta: PT. Rineka Cipta.

[2] Arikunto, S. (2005). Manajemen Penelitian. Jakarta: RinekaCipta.

[3] Arikunto, S. (2006). Metode Penelitian Kualitatif. Jakarta: Bumi Aksara

[4] Cahyono, Duto Sri. 2011. Penghobi burung semakin banyak, trafik OmKicau terus menanjak. Accessed from: http:/ / omkicau.com/2011/02/23/penghobi-burung-semakin-banyaktrafik-omkicau-terus-menanjak/. On 27 Juli 2013.

[5] Knapp, P dan Megan Watkins. (2005). Genre Text, Grammar: Technologies for Teaching and Assessing Writing. Australia: University of New South Wales Press Ltd.

[6] Suherdi, D. (2016) Pendidikan Bahasa bagi Keunggulan Bangsa. Bandung: UPI Press.

[7] Syathariah, S. (2011). Estafet Writing (menulis berantai). Yogyakarta: Grafina Mediacipta 
[8] Tarigan, D. (1995). Metodik Khusus Pengajaran Bahasa Indonesia di SD. Angkasa: Bandung

[9] Tarigan, D. (1996). Membina Keterampilan Menulis Paragraf dan Pengembangannya. Bandung: Angkasa.

[10] Tarigan, H. (1986). Menulis sebagai Suatu Keterampilan Berbahasa. Bandung: Angkasa.

[11] Tarigan, H. (1992). Pengajaran Analisis Kontrastif Bahasa. Bandung: Angkasa.

[12] Tarigan, H. (2008). Membaca sebagai Suatu Keterampilan Berbahasa. Bandung: Angkasa. 